ISSN1027-5495. Functional Materials, 23, No.3 (2016), p. 427-432

doi:http://dx.doi.org/10.15407/fm23.03.427

(C) 2016 - STC “Institute for Single Crystals"

\title{
Degradation of lignin in cassava residue with Phanerochaete chrysosporium by solid state cultivation
}

\author{
Bin Xu, Huixing Li, Chaojun Du, Ying Wang, Bin Li \\ School of Biological and Chemical Engineering, Nanyang Institute of \\ Technology, Nanyang 473004, P.R. China
}

Received April 22,2016

\begin{abstract}
Cassava residue is a lignocellulosic waste byproduct in cassava-based ethanol production. Bioconversion of this waste to methane is one choice to solve its disposal problem. The bioconversion of lignocellulosic wastes could be enhanced through lignin degradation by solid state cultivation (SSC) with Phanerochaete chrysosporium. In this study, effects of moisture content, veratryl alcohol concentration and $\mathrm{pH}$ on lignin degradation of $\mathrm{P}$. chrysosporium in solid cassava residue substrate cultivation were examined. Results showed that lignin degradation were significantly affected by moisture content and veratryl alcohol concentration. The optimal cultivation conditions for lignin degradation were $\mathrm{pH} 4.5$, moisture content $66 \%$ and veratryl alcohol concentration $5.70 \mathrm{mM} / \mathrm{kg}$. Within fourteen days of cultivation at these optimal conditions, lignin degradation mainly occurred in the first six days and lignin loss were 28.36 $\pm 0.25 \%$. Moreover, microscopic structure observation demonstrated that the structure of cassava residue was destroyed. The degradation of lignin and breakdown of the cassava residue structure by P. chrysosporium in SSC would provide a new approach to facilitate the bioconversion of cassava residue to methane in the future application.

Keywords: Cassava residue, Phanerochaete chrysosporium, lignin degradation, bioconversion.
\end{abstract}

Маниока остаток является побочным продуктом лигноцеллюлозных отходов производства этанола на основе маниоки. Биоконверсия этих отходов в метанесть один из способов, чтобы решить проблему его утилизации. Биоконверсия лигноцеллюлозных отходов может быть повышена за счет лигнина деградации под действием твердого культивирования состояния (SSC) по Phanerochaete Chrysosporium. В данном исследовании изучено влияние содержания влаги, концентрации вератрового спирта и рН на деградацию лигнина P. Chrysosporium в твердом маниока остатка. Результаты показали, что деградация лигнина значительно зависит от влажности и концентрации вератрового спирта. Оптимальные условия деградации лигнина были при $\mathrm{pH} 4,5$, содержании влаги $66 \%$ и концентрация вератрового спирта 5,70 ммоль/кг На протяжении четырнадцати дней культивирования при этих оптимальных условиях деградация лигнина в основном происходила на протяжении первых шести дней и потери лигнина были $28,36 \pm 0,25 \%$. Кроме того, микроскопические исследования структуры показали, что структура маниоки остатка была разрушена. Эти исследования помогут облегчить биоконверсию маниоки остатка метана в будущем приложении.

Деградація лігніну в маніоки залишку 3 Phanerochaete Chrysosporium твердотільною культивацією. Сюй, Чи Huixing, Chaojun Ду Iн Ван, Чи Бен

Маніока залишок є побічний продукт лигноцеллюлозных відходів виробництва етанолу на основі маніоки. Біоконверсія цих відходів в метан е один із способів, щоб вирішити проблему його утилізації. Біоконверсія лигноцеллюлозных відходів може бути підвищена за рахунок лігніну деградації під дією твердого культивування стану (SSC) з Phanerochaete Chrysosporium. У даному дослідженні вивчений вплив змісту вологи, концентрації 
вератрового спирту і pH на деградацію лігніну P. Chrysosporium в твердому маніока залишку. Результати показали, що деградація лігніну значно залежить від вологості і концентрації вератрового спирту. Оптимальні умови деградації лігніну були при $\mathrm{pH} 4,5$, змісті вологи 66\% і концентрація вератрового спирту 5,70 ммоль / кг Протягом чотирнадцяти днів культивування за цих оптимальних умов деградація лігніну в основному відбувалася протягом перших шести днів і втрати лігніну були $28,36 \pm 0,25 \%$. Крім того, мікроскопічні дослідження структури показали, що структура маніоки залишку була зруйнована. Ці дослідження допоможуть полегшити біоконверсію маніоки залишку метану в майбутньому застосуванні.

\section{Introduction}

Cassava residue is a waste byproduct with a large proportion of lignocellulosic components, namely cellulose, hemicellulose and lignin. The waste is generated from cassava-based ethanol production and approximately 0.3 million tons (dry weight) of it are generated in China per year. The waste poses a disposal problem and would even be more problematic in the future with increased industrial production of ethanol $[1,2]$. One way to solve the above problem is bioconversion of cassava residue to methane by anaerobic digestion $[2,3]$. However, due to the recalcitrant lignocellulosic structure, especially the lignin components, the efficiency of this process is low $[3,4]$.

Lignin is the most important factor limiting the bioconversion efficiency of lignocellulosic wastes because it is heterogenous, polymeric and hydrophobic [4-6]. Many methods have been investigated for the lignin removal, including chemical (alkali, wet oxidation, etc.), enzymatic and microbiological, or a combination of these. Chemical methods require high-energy and/or produce secondary waste. Enzymatic methods are economically unfeasible in large-scale processes. Microbiological methods employ lignindegrading microorganism to degrade lignin in lignocellulosic waste. This environmentally friendly and economical approach receives increased attention due to reduced energy, costs and wastes, simplified processes and equipments [7-9]. Among known lignin-degrading microbe, white-rot fungi are the most effective for lignin degradation $[9,10]$. Moreover, most researchers are interested in solid state fungal cultivation because it requires considerably lower nutrient supplementation and generates lesser wastewater compared to submerged fermentation $[11,12]$.

Phanerochaete chrysosporium is a typical white-rot fungus which produces extra-cellular ligninolytic enzymes (lignin peroxidase, $\mathrm{LiP}$ and manganese peroxidase, $\mathrm{MnP}$ ) that can degrade lignin, has been applied to degrade lignin and further enhance the bioconversion efficiency in a wide range of lignocellulosic wastes. Moreover, capacity and characteris- tics of lignin degradation vary with cultivation conditions and lignocellulosic species [13-18]. Supplementation of inducers can stimulate secretion of ligninolytic enzymes and enhance lignin degradation in feedstock. Shrestha et al. [15] tested effects of $\mathrm{Mn}^{2+}, \mathrm{H}_{2} \mathrm{O}_{2}$, and veratryl alcohol on lignin degradation of corn fiber by $P$. chrysosporium and found that inducers supplementation resulted in the improvement of lignin degradation. Moisture content had a significant effect on degradation of lignin. Shi et al. [19] reported that lignin degradation with $75 \%$ and $80 \%$ moisture content was approximately $6.0 \%$ more than $65 \%$ after 14 days of cultivation on cotton stalks. The stage of lignin degradation is also different in lignocellulosic species. Hatakka and Uusi-Rauva [20] reported that there was an initial lag period before significant lignin degradation occurred, mostly because $P$. chrysosporium needed to produce combination enzymes to breakdown cotton stalk and the degradation products were used as carbon sources. Whereas, some studies have shown that lignin degradation is consistent in SSC of $P$. chrysosporium on cotton stalk, and additional cultivation time is beneficial to overall lignin degradation [19].

To our best knowledge, there is no report on the application of SSC using $P$. chrysosporium to degrade lignin in cassava residue. Cultivation conditions of $P$. chrysosporium in solid cassava residue substrate cultivation have never been investigated. For the effective lignin degradation of cassava residue by SSC with $P$. chrysosporium, we carried out the optimization of cultivation conditions for lignin degradation by response surface methodology (RSM) for batch runs designed with a Box-Behnken design [21,22]. The optimal conditions were then utilized to culture $P$. chrysosporium for fourteen days and characteristics of degradation were investigated. Furthermore, the structural modification of cassava residue treated by $P$. chrysosporium was analyzed using scanning electronic microscope. The improved efficiency of lignin degradation and disintegration of structure is expected to be benefit in the future application of methane production by anaerobic digestion of cassava residue. 


\section{Materials and methods}

\subsection{Raw material}

The air-dried cassava residue was obtained from Yong Xiang ethanol Co., Ltd., Wujiang, China. The raw material was dried at $105^{\circ} \mathrm{C}$ until constant weight was obtained and then milled to pass through 40-mesh screen. Components of cassava residue were as follows: total organic carbon (TOC) $33.85 \pm 0.17 \%$; lignin, $20.19 \pm 0.22 \%$; hemicellulose, $10.49 \pm 0.20 \%$; cellulose, $31.46 \pm 0.63 \%$.

\subsection{Fungal strain and cultivation}

Phanerochaete chrysosporium CICC 40719 was utilized in this study. The fungus was bought from Beina Chuanglian Biological Research Institute and maintained on potato dextrose agar (PDA) plates at $4^{\circ} \mathrm{C}$. The conidia were obtained from 7-day old fungal cultures that were grown on PDA plates. Incubations were in 250-ml Erlenmeyer flasks containing ten gram cassava residue and four $10 \mathrm{~mm}$ agar plugs removed from PDA agar. Flasks were incubated at $30^{\circ} \mathrm{C}$ and a humidity of $70 \%$ in a mould cultivation incubator equipped with a humidifier (Model MJ-150, Zhongxin, China). After harvest, solid fractions were dried at $105^{\circ} \mathrm{C}$ until constant weight was obtained. The dry solids were used for analysis of lignin content and chemical oxygen demand (COD), respectively.

\subsection{Optimization of cultivation condi-} tions for lignin degradation by RSM

The lignin degradation was investigated by SSC of $P$. chrysosporium in cassava residue for fourteen days. A Box-Behnken design with three settings for each of three cultivation conditions ( $\mathrm{pH}$, moisture content and veratryl alcohol concentration) was run to optimize lignin loss and to explore the interactions between those technological variables. The experimental plan and levels of independent variables were shown in Table 1. $\mathrm{X}_{1}$ was $\mathrm{pH}$ of distilled water which was adjusted by $\mathrm{HCl}$ and further on mixed with cassava residue to change moisture content, and had a lower limit of 3.5 and a higher limit of $5.5 ; \mathrm{X}_{2}$ was the moisture content and was varied between $60 \%$ and $80 \%$. The lower and higher limits of $\mathrm{X}_{3}$, the veratryl alcohol concentrations were 0 and $6 \mathrm{mM} / \mathrm{kg}$, respectively. The development of design matrices and analysis of variance (ANOVA) for the variables were conducted using the SAS program (Version 8.0, SAS Institute, Cary, NC). The $p$-value of variables was calculated by SAS program with F-test and considered significant when $p$ value $<0.05$.
Table 1. Box-Behnken design to optimize conditions

\begin{tabular}{|c|c|c|c|c|}
\hline & & \multicolumn{3}{|c|}{ Coded levels } \\
\cline { 3 - 5 } Variables & Symbol & $\begin{array}{c}\text { Low } \\
(-1)\end{array}$ & $\begin{array}{c}\text { Mid } \\
(0)\end{array}$ & $\begin{array}{c}\text { High } \\
(1)\end{array}$ \\
\hline $\mathrm{pH}$ & $\mathrm{X}_{1}$ & 3.5 & 4.5 & 5.5 \\
\hline $\begin{array}{c}\text { Moisture content } \\
(\% \mathrm{w} / \mathrm{w})\end{array}$ & $\mathrm{X}_{2}$ & 60 & 70 & 80 \\
\hline $\begin{array}{c}\text { Veratryl alcohol } \\
\text { concentration } \\
(\mathrm{mM} / \mathrm{kg})\end{array}$ & $\mathrm{X}_{3}$ & 0 & 3 & 6 \\
\hline
\end{tabular}

\subsection{Analysis Methods}

TOC was determined with a total organic carbon analyzer (Model Toc-V, Shimadzu, Japan). COD was determined according to standard methods [23]. The content of lignin was determined according to Van Soest's method [24]. The loss of lignin (\%) was calculated by the following equation:

$$
\text { Loss }(\%)=\left(m_{0}-m\right) / m_{0} \times 100
$$

where, $m_{0}$ is the initial weight of lignin, $g ; m$ is the weight of lignin after incubation, $\mathrm{g}$.

\subsection{Scanning Electronic Microscope (SEM) Analysis}

Untreated cassava residue and six days treated cassava residue with $P$. chrysosporium were observed with a SEM (FEI Quanta 200, Holland) [3].

\section{Results and discussion}

\section{loss \\ 3.1 Cultivation conditions on lignin}

Previous reports of lignocellulosic wastes degraded by $P$. chrysosporium have shown that $\mathrm{Mn}^{2+}, \mathrm{H}_{2} \mathrm{O}, \mathrm{pH}$, moisture content, and veratryl alcohol concentration etc. had impacts on lignin degradation $[15,16,25]$. Based on our preliminary experiments, effects of $\mathrm{pH}$, moisture content and veratryl alcohol concentration on lignin loss were investigated with a Box-Behnken design. Fifteen trials were performed to locate optimal conditions for maximum lignin loss. The results were shown in Table 2. Owing to the complex nature of biological process, it is hard to explain distinctively the effects of all factors, which may interact with each other. Therefore, the overall effects of the variables on lignin loss were analyzed by the analysis of variance (Table 3) which was performed by the SAS program. The results showed that the effects of moisture content $\left(\mathrm{X}_{2}\right)$, quadratic term of moisture content $\left(\mathrm{X}_{2} * \mathrm{X}_{2}\right)$, veratryl alcohol concentration $\left(\mathrm{X}_{3}\right)$ and the quadratic term of veratryl 
Table 2. Lignin loss under different levels of variables

\begin{tabular}{|c|c|c|c|c|}
\hline Runs & $\mathrm{X}_{1}$ & $\mathrm{X}_{2}$ & $\mathrm{X}_{3}$ & Lignin Loss, $\%$ \\
\hline 1 & -1 & -1 & 0 & $27.86 \pm 0.42$ \\
\hline 2 & -1 & 1 & 0 & $8.18 \pm 0.84$ \\
\hline 3 & 1 & -1 & 0 & $28.45 \pm 0.54$ \\
\hline 4 & 1 & 1 & 0 & $5.90 \pm 0.77$ \\
\hline 5 & 0 & -1 & -1 & $26.87 \pm 0.59$ \\
\hline 6 & 0 & -1 & 1 & $30.73 \pm 0.12$ \\
\hline 7 & 0 & 1 & -1 & $9.08 \pm 0.54$ \\
\hline 8 & 0 & 1 & 1 & $10.26 \pm 0.75$ \\
\hline 9 & -1 & 0 & -1 & $28.23 \pm 0.40$ \\
\hline 10 & 1 & 0 & -1 & $27.28 \pm 0.55$ \\
\hline 11 & -1 & 0 & 1 & $30.92 \pm 0.23$ \\
\hline 12 & 1 & 0 & 1 & $30.10 \pm 0.36$ \\
\hline 13 & 0 & 0 & 0 & $28.01 \pm 0.27$ \\
\hline 14 & 0 & 0 & 0 & $27.33 \pm 0.64$ \\
\hline 15 & 0 & 0 & 0 & $27.20 \pm 0.51$ \\
\hline
\end{tabular}

Table 3. Analysis of variance (ANOVA) for the variables

\begin{tabular}{|c|c|c|c|c|}
\hline Source & DF & $\begin{array}{c}\text { Mean } \\
\text { square }\end{array}$ & F-value & p-value \\
\hline $\mathrm{X}_{1}$ & 1 & 1.50 & 3.14 & 0.14 \\
\hline $\mathrm{X}_{2}$ & 1 & 809.83 & 1703.48 & $<0.01$ \\
\hline $\mathrm{X}_{3}$ & 1 & 13.91 & 29.27 & $<0.01$ \\
\hline $\mathrm{X}_{1}{ }^{*} \mathrm{X}_{1}$ & 1 & 0.0003 & 0.0006 & 0.98 \\
\hline $\mathrm{X}_{1}{ }^{*} \mathrm{X}_{2}$ & 1 & 2.06 & 4.33 & 0.09 \\
\hline $\mathrm{X}_{1}{ }^{*} \mathrm{X}_{3}$ & 1 & 0.004 & 0.009 & 0.93 \\
\hline $\mathrm{X}_{2}{ }^{*} \mathrm{X}_{2}$ & 1 & 362.37 & 762.25 & $<0.01$ \\
\hline $\mathrm{X}_{2}{ }^{*} \mathrm{X}_{3}$ & 1 & 1.80 & 3.78 & 0.11 \\
\hline $\mathrm{X}_{3}{ }^{*} \mathrm{X}_{3}$ & 1 & 9.79 & 20.59 & $<0.01$ \\
\hline
\end{tabular}

alcohol concentration $\left(\mathrm{X}_{3} * \mathrm{X}_{3}\right)$ were significant, with $p$-value $<0.01$, while the interactions of $\mathrm{pH}$ and moisture content $\left(\mathrm{X}_{1}^{*} \mathrm{X}_{2}\right)$ was influential, because of $\mathrm{F}_{0.05}(1,5)=6.61>\mathrm{F}_{\mathrm{X} 1 * \mathrm{X} 2}>\mathrm{F}_{0.1}(1$, $5)=4.06$. It is suggested moisture content and veratryl alcohol concentration were significant conditions on lignin loss, whereas the $\mathrm{pH}$ had a less significant effect on lignin loss.

Moisture content significantly affected the lignin degradation of cassava residue, because water is a solvent for mass transfer and oxygen diffusion in SSC. Low moisture content would hamper fungal lignin degradation without providing sufficient water to fungal growth. On the other hand, high moisture content limited oxygen transfer, often inhibiting aerobic SSC and degradation of lignin as it is an oxidative process $[19,25]$. Supplementation of veratryl alcohol could improve the activity of ligninolytic enzymes and enhance lignin degradation since

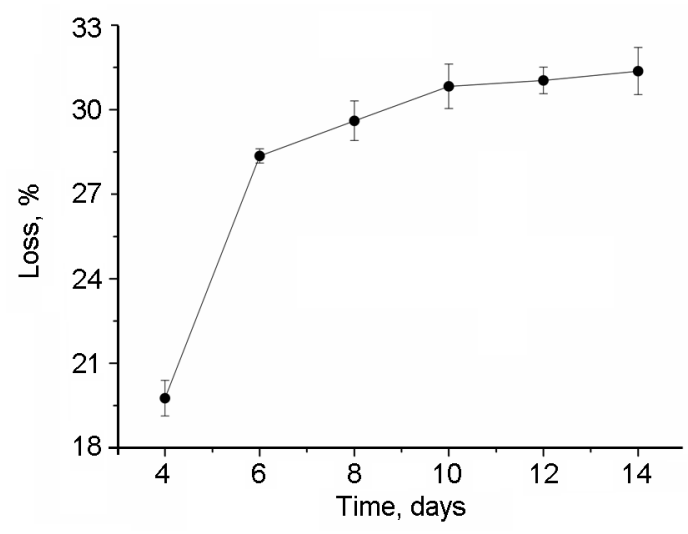

Fig. 1. Time-course profiles of cassava residue degradation on solid state cultivation with $P$. chrysosporium under the optimal cultivation conditions (moisture content of $66 \%, \mathrm{pH} 4.5$ and veratryl alcohol concentration of $5.70 \mathrm{mM} / \mathrm{kg}$ ).

veratryl alcohol was an inducer of ligninolytic enzymes $[15,16,26]$. Fungi usually grow and metabolize in an acid environment and $\mathrm{pH}$ of the environment decreases as organic acids accumulation during the cultivation of fungi $[27,28]$. The $\mathrm{pH}$ factor was the least important for performance of $P$. chrysosporium in the present investigation, and it is consistent with previous reports [29], as the chosen experimental range of $\mathrm{pH}$ (3.5-5.5) did not markedly affect the lignin degradation.

\subsection{Cassava residue degradation under the optimal cultivation conditions}

Optimal cultivation conditions were determined by the ridge max analysis, which computes the estimated ridge of maximum response for increasing radii from the center of original design [30]. The ridge max analysis indicated that maximum lignin loss was supposed to be $32.78 \%$ at $\mathrm{pH} 4.5$, moisture content $66 \%$ and veratryl alcohol concentration $5.70 \mathrm{mM} / \mathrm{kg}$ at the distance of the coded radius 1.0. Fig. 1 demonstrated that the time course profile of lignin degradation by $P$. chrysosporium under the optimal conditions. As shown in Fig. (1), after fourteen days of cultivation under the optimal conditions, the lignin loss was $31.37 \pm 0.84 \%$. Degradation characteristics of lignocellulosic biomass with $P$. chrysosporium was distinctive in cultivation conditions and its species [18-20]. The lignin degradation of cassava residue mainly occurred in the first six days of cultivation, and the lignin loss achieved $28.36 \pm 0.25 \%$, only approximately $3 \%$ increase in subsequent eight days of cultivation. Moreover, to investigate how much available matter in treated cassava residue would be left for methane production by anaerobic digestion, COD of the treated cassava residue was analyzed and compared with 


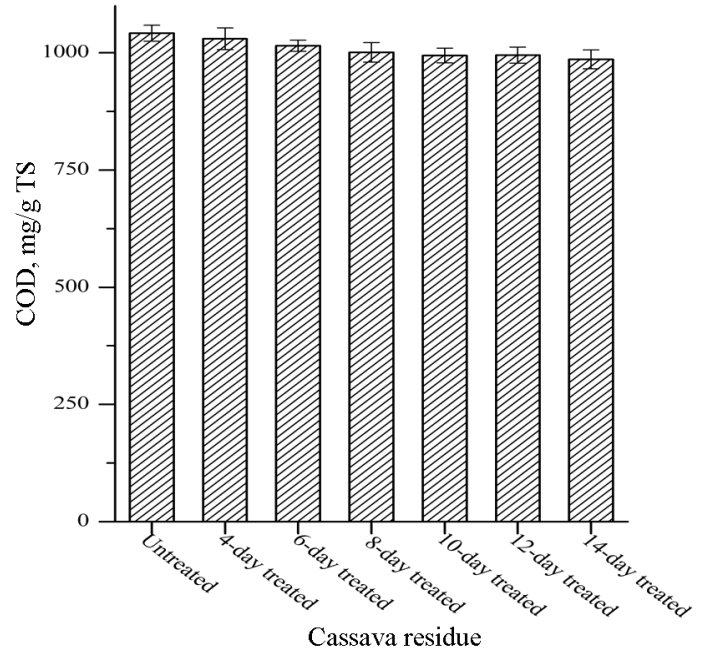

Fig. 2. Chemical oxygen demand of untreated cassava residue and the treated cassava residue.

that of untreated cassava residue. From the Fig. 2, it was found that the COD of treated cassava residue did not markedly decrease. These results suggested that the optimum of treated time was six days since methane productivity of treated lignocellulosic biomass was inversely correlation with its lignin content $[31,32]$.

\subsection{SEM Images of untreated and treat- ed cassava residue}

The morphological changes induced by $P$. chrysosporium were examined by scanning electronic microscope (SEM) to show structural modifications in cassava residue. As shown in Fig. 3A, untreated cassava residue had a contact and smooth flat surface and exhibited the rigid and connected structure. In contrast, structure of treated cassava residue was rugged and loosed, and many cracks and scars were observed though spores of $P$. chrysosporium were found on the surface of treated cassava residue (Fig. 3 B). Obviously, the morphology of cassava residue was changed dramatically after $P$. chrysosporium treatment, the initial connected structure was loosed and destroyed. These structural breakdown would benefit the bioconversion of cassava residue to methane since the destroyed structure would make the residue more accessible to the microorganisms involved in the biological process, resulted in higher bioconversion efficiency $[3,18]$

\section{Conclusions}

In this study, cultivation conditions and characteristics of lignin degradation of cassava residue by $P$. chrysosporium in solid state cultivation were investigated. The optimal cultivation conditions were $\mathrm{pH} 4.5$, moisture content $66 \%$ and veratryl alcohol concentra-
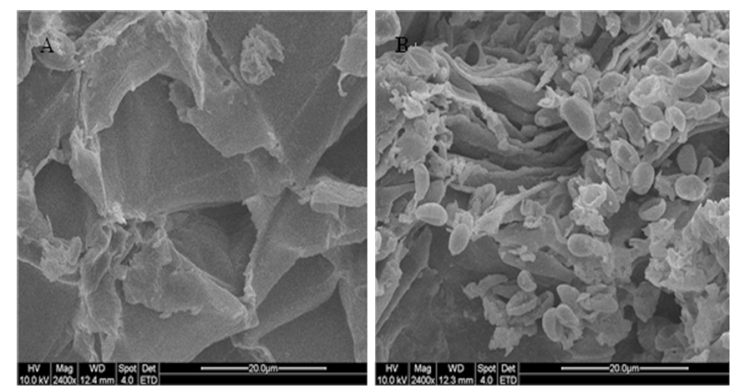

Fig. 3. SEM images of untreated and 6-day treated cassava residue with $P$. chrysosporium under the optimal cultivation conditions (moisture content of $66 \%, \mathrm{pH} 4.5$ and veratryl alcohol concentration of $5.70 \mathrm{mM} / \mathrm{kg}$ ). (A) untreated cassava residue with a rigid and connected structure; (B) after six days treated cassava residue with a rugged and loosed structure. Smaller bodies on the surface of treated cassava residue were spores of $P$. chrysosporium.

tion $5.70 \mathrm{mM} / \mathrm{kg}$. Within fourteen days of cultivation at these optimal conditions, lignin loss mainly occurred in the first six days, and the lignin loss achieved $28.36 \pm 0.25 \%$. In addition, microscopic structure observation demonstrated that the structure of cassava residue was breakdown. The degradation of lignin and disintegration of cassava residue structure provided the possibility of higher bioconversion efficiency in methane production which needs to be fully examined in the future study.

\section{Acknowledgements}

This work is financially supported by Key Technology Program of Henan Province (No. 152102110156).

\section{References}

1. H. Li, R. Zhang, L. Tang, J. Zhang, Z. Mao, Chin. J. Chem. Eng., 23, 227. 2015.

2. Q. H. Zhang, et al., Bioresour. Technol., 102, 8899, 2011.

3. Q. H. Zhang, L. Tang, J. H. Zhang, Z. G. Mao, L. Jiang, Bioresour. Technol., 102, 3958, 2011.

4. F. Monlau, A. Barakat, E. Trably, C. Dumas, et al. Crit. Rev. Env. Sci. Technol., 43, 260, 2013.

5. M. Tuomela, M. Vikman, A. Hatakka, M. Itдvaara, Bioresour. Technol., 72, 169, 2000.

6. D. E. Akin, Biofuel Bioprod. Bior., 2, 288, 2008.

7. N. Mosier, C. Wyman, B. Dale et al., Bioresour. Technol., 96, 673, 2005.

8. A. T. Martinez, F. J. Ruiz-Duecas, M. J. Martmnez et al., Curr. Opin. Biotechnol., 20, 348, 2009.

9. R. Gupta, G. Mehta, Y. P. Khasa, R. C. Kuhad, Biodegradation, . 22, 797, 2011.

10. H. L. Huang, et al., Int. Biodeterior. Biodegrad., 61, 331, 2008. 
11. R. R. Singhania, A. K. Patel, C. R. Soccol, A. Pandey, Biochem. Eng. J., 44, 13, 2009.

12. R. P. Tengerdy, G. Szakacs, Biochem. Eng. J., 13, 169, 2003.

13. A. Ghosh, B. C. Bhattacharyya, Bioprocess Eng., 20, 297, 1999

14. S. Basu, R. Gaur, J. Gomes, T. R. Sreekrishnan, V. S. Bisaria, J. Biosci. Bioeng., 93, 25, 2002.

15. P. Shrestha, M. Rasmussen, S. K. Khanal, et al., J. Agric. Food Chem., 56, 3918, 2008.

16. D. Singh, S. Chen, Appl. Microbiol. Biotechnol., 81, 399, 2008.

17. J. S. Bak, J. K. Ko, I. G. Choi, Y. C. Park, et.al., Biotechnol. Bioeng., 104, 471, 2009.

18. L. Zhao, et al., Bioresour. Technol., 114, 365, 2012.

19 J. Shi, M. S. Chinn, R. R., Bioresour. Technol., 99, 6556, 2008.

20. A. I. Hatakka, A. K. Uusi-Rauva, Eur. J. Appl. Microbiol. Biotechnol., 17, 235, 1983.

21. X. Chen, J. H. Wang, D. S. Li, Biochem. Eng. J., 34, 179, 2007.
22. S. L. C. Ferreira, et al., Anal. Chim. Acta., 597, 179, 2007.

23. K. Wang, et al., Bioresour. Technol., 148, 453, 2013.

24. M. Yu, G. Zeng, Y. Chen, H. Yu, et al., Process Biochem., 44, 17, 2009.

25. C. Wan, Y. Li, Biotechnol. Adv., 30, 1447, 2012.

26. F. Gassara, S. K. Brar, R. Tyagi, R. P. et al., Biotechnol. Bioproc. E., 16, 343, 2011.

27. S. H. Denison, Fungal Genet. Biol., 29, 61, 2000.

28. F. Zadraћil, H. Brunnert, J. Appl. Microbiol. Biotechnol., 11,. 183, 1981.

29. M. Schubert, S. Mourad, F. Schwarze, Appl. Microbiol. Biotechnol., 85, 703, 2010.

30. X. Zou, H. Hang, C. Chen, J. Chu, et al., J. Ind. Microbiol. Biotechnol., 35, 1637, 2008.

31. R. Amirta, T. Tanabe, T. Watanabe, et al., J. Biotechnol., 123, 71, 2006.

32. H. Take, Y. Andou, Y. Nakamura, F. Kobayashi, et al., Biochem. Eng. J., 28, 30, 2006. 